\title{
The effects of composted pineapple residue return on soil properties and the growth and yield of pineapple
}

\author{
C. H. Liu ${ }^{1 *}$ Y. Liu ${ }^{1}$, C. Fan ${ }^{1}$ and S. Z. Kuang ${ }^{1}$ \\ ${ }^{I}$ Institute of Fruit Tree Research, Guangdong Academy of Agricultural Sciences, 510640, Guangzhou, P. R. China; Key laboratory \\ of south subtropical fruit biology and genetic resource utilization, Ministry of Agriculture, 510640, Guangzhou, P. R. China. \\ "Corresponding author: founderlch@126.com
}

\begin{abstract}
:
A field experiment was conducted to investigate the influence of composted pineapple residue return (CPRR) on soil bio-chemical properties and the growth performance of next-cropped pineapple plants. The results suggested that CPRR markedly decreased the soil bulk density and increased the contents of available P and K. CPRR significantly increased the abundance of bacteria and actinomycetes, and the activities of catalase, acid phosphatase and invertase in the soil were notably heightened. Growth characteristics, including the plant height, length of leaves and roots, leaf width, number of leaves and fresh weight of the aboveground and belowground parts were significantly increased by CPRR. The contents of chlorophyll, soluble sugars, and soluble protein, as well root vigor were also markedly increased. CPRR also increased the fruit transverse and longitudinal diameters, weight and yield of next-cropped pineapple.
\end{abstract}

Keywords: Pineapple, residue return, compost, soil properties, growth performance

\section{Introduction}

Plant residue, a by-product of plant production systems, is an important biological resource, comprising approximately $50 \%$ of the total biomass of crops. It is estimated that a total of approximately 2 billion tons of residue are produced annually worldwide. The return of residue to the field is a useful cultural practice to improve both soil fertility and soil organic carbohydrate storage (Aynehband et al., 2010; Lou et al., 2011).

Composting, as one method of residue return, is a widely acceptable alternative for converting waste into a more useful eco-friendly fertilizer and is known to improve soil fertility (Gaind and Gaur, 2003; Tejada and Gonzalez, 2006). With the increasing demand for organic fruits and vegetables, the return of composted residue to fields as organic manure has recently attracted attention from farmers and scientists due to the positive effects of soil amendment while reducing the use of synthetic fertilizer (Chikae et al., 2006; Gabhane et al., 2012). 
Due to the cellulose in plant residue, returning this material as compost decreases the bulk density, promotes the formation of soil aggregate structure, and increases the efficiency of water in soil (Edwards et al., 2000; Tejada and Gonzalez, 2003). There were certain amount of carbohydrate, $\mathrm{N}, \mathrm{P}, \mathrm{K}$, and other nutrients in residues, the compost applied to soil was transferred to organic matter and enhanced the soil fertility level (Zayed and Abdel-Motaalet, 2005; Benito et al., 2006; Ribeiro et al., 2007; Roca-Pérez et al., 2009). Due to the increase in the organic matter content and improvement of the physical-chemical properties, residue returned as compost supplies a better soil environment and an abundant carbohydrate and nitrogen source that benefits the growth of beneficial microorganisms (Zayed and Abdel-Motaalet, 2005; Ros et al., 2006; Bougnom et al., 2010). Therefore, residue returned as compost results in enhanced soil enzyme activity by increasing the amount of enzymes and their substrates in the soil (Ros et al., 2006).

Owning to the benefits on soil fertility, enzymes and microorganisms, residue returned as compost improves the condition of agricultural soils and increases root vigor and such other physiological characteristics as the chlorophyll content, photosynthetic rate and carbohydrate content of plants (Joshi et al., 2009; Yogev et al., 2009). Accordingly, composted residue return increases the growth rate, stimulates plant performances and enhances the yield and quality of crops (Abdelhamid et al., 2004; Tejada and Gonzalez, 2006; Roca-Pérez et al., 2009).

Pineapple [Ananas comosus (L.) Merr.] is an important fresh fruit that is widely cultivated in tropical and subtropical areas, with approximately 90 150 tons of by-products (leaves and stems) generated after fruit harvest per hectare. A preliminary study suggested that fresh pineapple residue contains $678.6 \mathrm{~g} \mathrm{~kg}^{-1}$ organic matter, $10.75 \mathrm{~g} \mathrm{~kg}^{-1}$ total $\mathrm{N}, 0.83 \mathrm{~g}$ $\mathrm{kg}^{-1} \mathrm{P}_{2} \mathrm{O}_{5}$ and $11.4 \mathrm{~g} \mathrm{~kg}^{-1} \mathrm{~K}_{2} \mathrm{O} 65.5 \mathrm{~g} \mathrm{~kg}^{-1}$. Furthermore, the rational utilization of pineapple residue resources is becoming an inevitable requirement for the sustainable development of agriculture and the economy. It has been reported that more than 35 weeks was required for the decomposition of pineapple residue when the material was directly shredded and incorporated in the soil (Tam and Magistad, 1935). In some areas, pineapple residues are burned in situ prior to being returned to the soil (Ahmed and Husni, 2010); however, this process results in the loss of plant nutrients and pollutes the environment (Heard et al., 2006). Therefore, many growers compost the pineapple residue before returning it to the soil.

To date, there is little available information about the effects of composted pineapple residue return on the bio-chemical properties of soil and the growth performance of the next-cropped pineapple plants. Accordingly, the purpose of this work was to examine the influence of composted pineapple residue return (CPRR) to the field on the physical-chemical and biological properties of soil, including fertility, enzyme activity and microbial diversity. Additionally, we examined the effects on the growth characteristics and physiological parameters of the next-cropped pineapple plants and fruit yield.

\section{Materials and Methods}

\subsection{Site description}

A field experiment was conducted in 2011-2012 at a commercial orchard located in the Shenwan region of Zhongshan $\left(22^{\circ} 11^{\prime} \mathrm{N}-22^{\circ} 47^{\prime} \mathrm{N} ; 113^{\circ} 09^{\prime} \mathrm{E}-113^{\circ} 46^{\prime} \mathrm{E}\right)$, Guangdong Province, P. R. China, to investigate the effects of pineapple residue returned as compost on the bio-chemical properties of soil and growth performance of pineapple plants and fruits. The local climate is characterized by a southern subtropical monsoon climate, with a mean annual precipitation of over 1791 $\mathrm{mm}$ that mostly occurs from March to September, and an average annual air temperature at approximately $22.2{ }^{\circ} \mathrm{C}$. The monthly average temperature reaches a high of approximately $28.5{ }^{\circ} \mathrm{C}$ between July and August, and the low monthly average occurs from 
December to February at approximately $13.6{ }^{\circ} \mathrm{C}$. The soil type of the experimental area is a sandy loam soil of $\mathrm{pH} 4.0$, with $15.0 \mathrm{~g} \mathrm{~kg}^{-1}$ organic matter, $91.05 \mathrm{mg}$ $\mathrm{kg}^{-1}$ available $\mathrm{N}, 18.55 \mathrm{mg} \mathrm{kg}^{-1}$ available $\mathrm{P}$ and $27.0 \mathrm{mg}$ $\mathrm{kg}^{-1}$ available $\mathrm{K}$ at $0 \sim 15 \mathrm{~cm}$ depth.

\subsection{Composting}

The pineapple residue was uprooted in February 2011 and machine broken into pieces of $3 \sim 5 \mathrm{~cm}$ in length and width on March 2, 2011. The next day, the obtained pieces $(2000 \mathrm{~kg})$ were mixed with a commercial straw-rotting microbial mixture $(2 \mathrm{~kg})$ to accelerate the composting process. The composting pile was stirred manually and covered with plastic film after the initial water content was adjusted to approximately $65 \%$. The moisture content was maintained at approximately $60 \%$ throughout the active composting period. The temperature was monitored each day and was controlled to not exceed $60 \sim 65{ }^{\circ} \mathrm{C}$ by adding water as necessary and turning the mixture manually to maintain porosity. The composting process ended on April 14, 2011, after the temperature decreased below $30^{\circ} \mathrm{C}$ and did not increase, and the compost was exposed to sunlight for drying.

\subsection{Experimental treatments}

The experiment was conducted on April 18, 2011 and was arranged as a random block design with three replications and two treatments. Treatment CPRR consisted of pineapple residue compost (40 $000 \mathrm{~kg} \mathrm{ha}^{-1}$ ) evenly spread over the field and raked into the topsoil $(0 \sim 30 \mathrm{~cm})$, whereas no compost was applied in treatment CK (control). One block was a replication, and each block was approximately $15 \mathrm{~m}^{2}$ in area $(1 \mathrm{~m} \times 15 \mathrm{~m})$. The composted pineapple residue contained $30 \%$ water, $232.1 \mathrm{~g} \mathrm{~kg}^{-1}$ organic matter, $12.2 \mathrm{~g} \mathrm{~kg}^{-1}$ total $\mathrm{N}, 7.1 \mathrm{~g} \mathrm{~kg}^{-1} \mathrm{P}_{2} \mathrm{O}_{5}$ and $13.8 \mathrm{~g} \mathrm{~kg}^{-1}$ $\mathrm{K}_{2} \mathrm{O}$.

At approximately $35 \mathrm{~cm}$ in height, sucker seedlings of pineapple cultivar 'Shenwan' were transplanted to the experimental field on April 18, 2012. The plant-to-plant distance within the rows and between the rows was $40 \mathrm{~cm}$ each. A total of 70 plants were cultivated in one plot. No other fertilizer was applied during the entire post-planting period.

\subsection{Sampling and measurement of parameters}

The soil and plants were sampled on September 26, 2011, approximately 160 days after the initiation of experiment. To assay the soil properties, two soil samples were randomly sampled from every block at $0 \sim 15 \mathrm{~cm}$ depth. The soil for the bulk density determination was sampled using a ring sampler (ring diameter of $6 \mathrm{~cm}$ and sampling depth of $2 \mathrm{~cm}$ ) and was preserved in an aluminum specimen box prior to transport to the lab. The soil samples for the enzyme and microbial parameter measurements were preserved in refrigerator at $4{ }^{\circ} \mathrm{C}$ prior to the measurements. On the same day, the pineapple plants were randomly sampled from every block to determine the growth performance characteristics and physiological parameters of the leaves and roots. The leaf samples for the physiological parameter measurements were sampled from the mid part of the 10 th to 15 th leaves, as counted from the center of the pineapple plants.

The organic matter content of the soil was determined by oxidation with $\mathrm{K}_{2} \mathrm{Cr}_{2} \mathrm{O}_{7}$ (LY/T1237-1999). The available N, P and $\mathrm{K}$ contents of the soil were determined based on standard assays (LY/T12291999, LY/T1233-1999/5, and LY/T1236-1999, respectively). The urease activity in the soil was determined according to Shi (1995) and was expressed as milligrams of ammonium released per kilogram of soil per hour $\left(\mathrm{mg} \mathrm{kg}^{-1} \mathrm{~h}^{-1}\right)$. The catalase activity was measured by titration with $0.1 \mathrm{~mol} \mathrm{~L}^{-1} \mathrm{KMnO}_{4}$ (Soil Microbial Research Lab, Institute of Soil Science, Chinese Academy of Sciences, 1985). The activity was expressed as milliliters of $\mathrm{KMnO}_{4}$ used per gram of soil per hour $\left(\mathrm{mL} \mathrm{g}^{-1} \mathrm{~h}^{-1}\right)$. The determination of the acid phosphatase activity was based on that of Zhao and Jiang (1986), and the activity was expressed as micrograms of paranitrophenol used per gram of soil 
per hour $\left(\mu \mathrm{g} \mathrm{g}^{-1} \mathrm{~h}^{-1}\right)$. The activity of invertase was determined based on a titration with $0.1 \mathrm{~mol} \mathrm{~L}^{-1}$ $\mathrm{Na}_{2} \mathrm{~S}_{2} \mathrm{O}_{3}$ (Soil Microbial Research Lab, Institute of Soil Science, Chinese Academy of Sciences, 1985), and the activity was expressed as milliliter of $\mathrm{Na}_{2} \mathrm{~S}_{2} \mathrm{O}_{3}$ used per kilogram of soil per hour $\left(\mathrm{mL} \mathrm{kg}^{-1} \mathrm{~h}^{-1}\right)$. The diversity of bacteria, fungi, and actinomycetes in the soil was measured by the dilution-plate method of Zhang (2007). The bacteria were cultured using beef cream-peptone culture medium. The fungi were cultured using Modified Martin Agar Medium, and the actinomycetes were cultured using Gauze's Medium No.1.

The plant height, leaf length and width, and root length were measured using a ruler. The leaf length and leaf width referred to the length of the longest leaf and its width of the middle part, respectively. The fresh weights of the aboveground and belowground parts were determined using a steelyard balance and electronic balance, respectively. The number of leaves and roots reflected the fresh leaves and roots.

The content of chlorophyll was determined using the method reported by Li et al. (2005), ethanol-acetone solution $(v / v 1: 1)$ extraction. The soluble sugar and soluble protein contents were evaluated according to $\mathrm{Li}$ (2000). The root vigor detection was based on TTC reduction according to Zhang (2007).

On July 3, 2012, fifteen pineapple fruits with similar degrees of maturity (shell color) were harvested from each block. The transverse and longitudinal diameters of the fruits were determined using a vernier caliper, and the weight per fruit (without crown) was measured using an electronic balance. The yield per plot referred to the fresh weight of all the harvested pineapple fruits in each block ( $\mathrm{kg}$ per plot).

\subsection{Statistical analysis}

The data were tested for statistical significance using the analysis of variance package included in Microsoft Excel 2003 and SPSS Statistics 17.0.
Mean comparisons were performed using the t-test. A probability level of $p \leq 0.05$ was considered significant.

\section{Results and Discussion}

\subsection{Soil physical-chemical properties}

The bulk density of soil characterizes the weight, degree of curing and content of organic matter. Soil with a low bulk density has a higher total porosity and respiration rate, with a higher water holding capacity, providing a better condition for crops. As presented in Table 1 , the bulk density of the CPRR soil $\left(1.01 \mathrm{~g} \mathrm{~cm}^{-}\right.$ $\left.{ }^{3}\right)$ was significantly decreased when compared with the CK soil $\left(1.68 \mathrm{~g} \mathrm{~cm}^{-3}\right)$. This result confirmed that the return of residue as compost decreased the bulk density of the soil (Edwards et al., 2000; Abdelhamid et al., 2004; Evanylo et al., 2008).

With respect to the soil chemical properties, the organic matter content of CPRR was $21.5 \mathrm{~g} \mathrm{~kg}^{-1}$, $19.4 \%$ higher than CK at $18.0 \mathrm{~g} \mathrm{~kg}^{-1}$. Similarly, the available $\mathrm{N}, \mathrm{P}$ and $\mathrm{K}$ contents of CPRR increased by $10 \%, 59.8 \%$ and $145.1 \%$, respectively, when compared with CK. Statistical analyses showed that the available $\mathrm{P}$ and $\mathrm{K}$ contents of the CPRR soil were significantly heightened $(p<0.05)$. These results suggested that the CPRR treatment enhanced the fertility of the soil, an observation in agreement with previous studies (Kowaljow and Mazzarino, 2007; Courtney and Mullen, 2008; Sommer et al., 2011) reporting that residue returned as compost increased the organic matter and N, P and K contents of soil. However, a significant difference was not observed for the organic matter and available $\mathrm{N}$ when compared with $\mathrm{CK}$ in the present work. The most likely reason for the lack of marked increase is due to the enhanced microbial consumption of the high amount of $\mathrm{C}$ and $\mathrm{N}$ in the returned pineapple compost. 
Table 1 Effects of CPRR on soil physical-chemical properties

\begin{tabular}{llllll}
\hline Treatment & $\begin{array}{l}\text { Bulk } \\
\text { density } \\
\left(\mathrm{g} \mathrm{cm}^{-3}\right)\end{array}$ & $\begin{array}{l}\text { Organic } \\
\text { matter } \\
\left(\mathrm{g} \mathrm{kg}^{-1}\right)\end{array}$ & $\begin{array}{l}\text { Available N } \\
\left(\mathrm{mg} \mathrm{kg}^{-1}\right)\end{array}$ & $\begin{array}{l}\text { Available P } \\
\left(\mathrm{mg} \mathrm{kg}^{-1}\right)\end{array}$ & $\begin{array}{l}\text { Available K } \\
\left(\mathrm{mg} \mathrm{kg}^{-1}\right)\end{array}$ \\
\hline CPRR & $1.01 \pm 0.01^{*}$ & $21.5 \pm 2.1$ & $440.0 \pm 11.5$ & $163.0 \pm 29.7^{*}$ & $1148.7 \pm 174.8^{*}$ \\
$\mathrm{CK}$ & $1.68 \pm 0.06$ & $18.0 \pm 1.7$ & $400.0 \pm 111.3$ & $102.4 \pm 4.4$ & $468.7 \pm 139.7$ \\
\hline
\end{tabular}

Note: Values with * within a column are significantly different by the t-test $(p=0.05)$

Table 2. Effects of CPRR on the abundance of soil microorganisms

\begin{tabular}{llll}
\hline Treatment & $\begin{array}{l}\text { Bacteria } \\
\left(\times 10^{6} \mathrm{cfug}^{-1}\right)\end{array}$ & $\begin{array}{l}\text { Fungi } \\
\left(\times 10^{4} \mathrm{cfu} \mathrm{g}^{-1}\right)\end{array}$ & $\begin{array}{l}\text { Actinomycetes } \\
\left(\times 10^{4} \mathrm{cfu} \mathrm{g}^{-1}\right)\end{array}$ \\
\hline CPRR & $4.29 \pm 0.88^{*}$ & $9.75 \pm 6.94$ & $7.99 \pm 5.66^{*}$ \\
CK & $0.95 \pm 0.41$ & $5.30 \pm 0.96$ & $0.008 \pm 0.0003$ \\
\hline
\end{tabular}

Note: Values with * within a column are significantly different by the t-test $(p=0.05)$

\subsection{Soil microorganisms}

Bacteria are responsible for the decomposition of organic matter of soil. Fungi are engaged in the decomposition of organic matter and the transformation of proteins into soluble $\mathrm{N}$ nutrients, amino acid and ammonium, which can be taken up by plants. Actinomycetes are known to decompose the recalcitrant components of plant and animal matter to humus and to transform plant and animal debris into organic matter. With respect to microorganisms (Table 2), the CPRR bacterial abundance was 3.51 times higher than that of CK, and the CPRR fungal population increased by $84.0 \%$. The actinomycetes increased from $0.008 \times 10^{4} \mathrm{cfu} \mathrm{g}^{-1}(\mathrm{CK})$ to $7.99 \times 10^{4}$ cfu $\mathrm{g}^{-1}$ (CPRR). The bacterial and actinomycetes were significantly increased by the CPRR treatment. These results suggested that the CPRR treatment increased the soil microorganisms, in accordance with previous studies (Zayed and Abdel-Motaal,
2005; Ros et al., 2006; Gandolfi et al., 2010; Bernard et al., 2012).

The actions of these three types of microorganisms in the soil accelerated the decomposition of the pineapple residue and enhanced the transfer of organic matter and other nutrients to the soil, providing increased nutrition for the growth of the next-cropped pineapple plants. There was no significant difference, however, in the fungal abundance between CPRR and CK. Because a large amount of $\mathrm{C}$ and $\mathrm{N}$ sources are needed for fungal reproduction, the lack of organic matter and available $\mathrm{N}$ enhancement may be the reason why the fungi were not notably increased by the CPRR treatment in this study.

\subsection{Activities of soil enzymes}

Urease is responsible for the hydrolysis of urea fertilizer applied to the soil into $\mathrm{NH}_{3}$ and $\mathrm{CO}_{2}$ with the concomitant rise in the soil $\mathrm{pH}$, and the activity of urease is often used 
to characterize the $\mathrm{N}$ content of the soil (Makoi and Ndakidemi, 2008). As presented in Table 3, the activity of urease was increased from $70.1 \mathrm{mg} \mathrm{kg}^{-1} \mathrm{~h}^{-1}$ to 89.2 $\mathrm{mg} \mathrm{kg}{ }^{-1} \mathrm{~h}^{-1}$ following the CPRR treatment; however, a significant difference was not observed. This result was similar to a previous study (Ros et al., 2006). Activity of soil urease is positively correlated to the contents of organic matter and available N. In this work, the content of available $\mathrm{N}$ was not markedly increased after CPRR treatment when compared to $\mathrm{CK}$, which likely explains why the urease activity was not significantly increased by the CPRR treatment.

The catalase enzyme is known to decompose the hydrogen peroxide in organic matter into water and oxygen by transferring protons and electrons from substrates to acceptors. These processes are part of the respiration pathways of soil microorganisms and are closely related to the type of soil and soil air-water conditions. In this study, the activity of catalase of CPRR was 1.22 times higher than that of CK (Table 3), and the statistical analysis indicated that the catalase activity was significantly increased by the CPRR treatment. The increasing activity of soil catalase after CPRR treatment contributes to the decomposition of excess hydrogen peroxide in the soil and protects the pineapple plants against the accumulation of hydrogen peroxide in the soil.
Acid phosphatase is a type of enzyme that is capable of catalyzing the hydrolysis of the anhydrides of phosphoric acid. In soil ecosystems, acid phosphatase is believed to play critical roles in $\mathrm{P}$ cycles and is used to characterize the level of P in the soil (Makoi and Ndakidemi, 2008). The acid phosphatase activity in CPRR was increased by 96.3\% compared with CK (Table 3), an observation that was consistent with previous studies (Ros et al., 2006; Saha et al., 2008). In this study, this increases in the acid phosphatase activity in CPRR and CK was in agreement with the increasing of content of available $P$, which further suggested that the CPRR treatment increased the availability of soil $\mathrm{P}$, contributing to the growth of the pineapple plants and fruits.

Invertase is responsible for the hydrolysis of saccharides, stimulating $\mathrm{C}$ cycles, substance transition, and energy exchange in soil. The activity of invertase is related to the fertility of soil and is used to define the curing condition and accumulating density of organic matter. In this study, the invertase activity in CPRR was increased by 1.42 times when compared with CK (Table 3). This observation was similar to a previous report and indicated that the CPRR treatment augmented the activity of soil invertase, which benefits the curing and transfer of $\mathrm{C}$ and $\mathrm{N}$ in soil (Zhang et al., 2011).

Table 3. Effects of CPRR on soil enzyme activities

\begin{tabular}{lllll}
\hline Treatment & $\begin{array}{l}\text { Urease } \\
/ \mathrm{mg} \mathrm{kg}^{-1} \mathrm{~h}^{-1}\end{array}$ & $\begin{array}{l}\text { Catalase } \\
/ \mathrm{mL} \mathrm{g}^{-1} \mathrm{~h}^{-1}\end{array}$ & $\begin{array}{l}\text { Acid } \\
\text { phosphatase } \\
/ \mathrm{\mu g} \mathrm{g}^{-1} \mathrm{~h}^{-1}\end{array}$ & $\begin{array}{l}\text { Invertase } \\
/ \mathrm{mL} \mathrm{kg}^{-1} \mathrm{~h}^{-1}\end{array}$ \\
\hline CPRR & $89.2 \pm 7.1$ & $2.85 \pm 0.9^{*}$ & $299.7 \pm 15.2^{*}$ & $46.4 \pm 24.1^{*}$ \\
$\mathrm{CK}$ & $70.1 \pm 3.1$ & $1.28 \pm 0.1$ & $152.7 \pm 14.5$ & $19.2 \pm 0.6$ \\
\hline
\end{tabular}

Note: Values with ${ }^{*}$ within a column are significantly different by the t-test $(p=0.05)$ 


\subsection{Plant growth performance}

Table 4 provides the growth performance parameters of the next-cropped pineapple plants. The results showed that the pineapple plant growth was promoted by the CPRR treatment: the plant height, leaf length, leaf width and root length in the CPRR treatment were increased by $32.9 \%, 35.8 \%, 53.8 \%$ and $53.9 \%$, respectively, when compared with CK. Furthermore, the statistical analysis indicated that the above parameters were notably increased by the CPRR treatment $(p<0.05)$. The numbers of leaves and roots were increased by $23.9 \%$ and $44.8 \%$, respectively, after the CPRR treatment, with the leaf number being particularly increased when compared with CK $(p<0.05)$.
The fresh weight of the aboveground and belowground parts of CPRR were increased by $91.2 \%$ and $23.4 \%$, respectively, when compared with $\mathrm{CK}$, and the statistical analysis showed that the results were significant $(p<0.05)$.

The above results revealed an enhancement in the growth of the pineapple plants in the CPRR treatment, and similar findings were reported in previous studies (Courtney and Mullen, 2008; Caballero et al., 2009; Traversa et al., 2010). Furthermore, previous studies stated that certain physiological parameters, such as nutrient uptake, root vigor, chlorophyll content, and soluble sugar and protein contents were improved through the application of compost (Ribeiro et al., 2007; Caballero et al., 2009).

Table 4. Effects of CPRR on the growth of next-cropped pineapple plants

\begin{tabular}{lllllllll}
\hline Treatment & $\begin{array}{l}\text { Plant } \\
\text { height } \\
(\mathrm{cm})\end{array}$ & $\begin{array}{l}\text { Leaf } \\
\text { length } \\
(\mathrm{cm})\end{array}$ & $\begin{array}{l}\text { Leaf } \\
\text { width } \\
(\mathrm{cm})\end{array}$ & $\begin{array}{l}\text { Root } \\
\text { length } \\
(\mathrm{cm})\end{array}$ & $\begin{array}{l}\text { Number } \\
\text { of } \\
\text { leaves }\end{array}$ & $\begin{array}{l}\text { Number } \\
\text { of } \\
\text { roots }\end{array}$ & $\begin{array}{l}\text { Fresh weight } \\
\text { of } \\
\text { aboveground } \\
\text { parts }(\mathrm{g})\end{array}$ & $\begin{array}{l}\text { Fresh weight } \\
\text { of } \\
\text { belowground } \\
\text { parts }(\mathrm{g})\end{array}$ \\
\hline CPRR & $95.3 \pm 1.2^{*}$ & $91.0 \pm 1.2^{*}$ & $6.0 \pm 0.2^{*}$ & $25.7 \pm 0.9^{*}$ & $36.3 \pm 0.9^{*}$ & $54.0 \pm 4.7$ & $1083.3 \pm 83.3^{*}$ & $41.1 \pm 2.9^{*}$ \\
CK & $71.7 \pm 0.9$ & $67.0 \pm 2.3$ & $3.9 \pm 0.1$ & $16.7 \pm 1.2$ & $29.3 \pm 0.3$ & $37.3 \pm 9.1$ & $566.7 \pm 33.3$ & $33.3 \pm 2.7$ \\
\hline
\end{tabular}

Note: Values with ${ }^{*}$ within a column are significantly different by the t-test $(p=0.05)$

\subsection{Physiological parameters}

The chlorophyll content reflects the plant photosynthetic assimilation ability and photosynthetic rate. In this study, the contents of chlorophyll a and chlorophyll b in CPRR were increased by $30.7 \%$ and $30.4 \%$, respectively, when compared with CK (Table 5), with the statistical analyses showing that the results were significant $(p<0.05)$. These results parallel previous studies on rice, okra and gerbera (Tejada and Gonzalez, 2006; Siddiqui et al., 2008; Caballero et al., 2009).
The contents of soluble sugar and protein are related to the growth potential and stress-resistance ability of plants. As presented in Table 5, the soluble sugar content in CPRR was increased by $39.6 \%$ and that for soluble protein by $29.5 \%$. Significant differences were observed for both the soluble sugar and protein when compared with $\mathrm{CK}(p<0.05)$, which was consistent with the previous results of Ribeiro et al. (2007) and Caballero et al. (2009).

Additionally, Abdel-Sabour and E1-Seoud (1996) and Tejada and Gonzalez (2006) stated that applying 
compost enhanced the root uptake activity of such nutrients as $\mathrm{N}, \mathrm{P}, \mathrm{K}, \mathrm{Ca}$ and $\mathrm{Mg}$. The root vigor reflects the growth performance of plants and the nutrient absorptive capacity of the roots.
In the present study, the root vigor of the CPRR plants was significantly increased by $48.3 \%$ (Table $5)$, in accordance with the results of Huang et al. (2009).

Table 5. Effects of CPRR on certain physiological parameters of pineapple plants

\begin{tabular}{llllll}
\hline Treatment & $\begin{array}{l}\text { Chlorophyll a } \\
\left(\mathrm{mg} \mathrm{g}^{-1}\right)\end{array}$ & $\begin{array}{l}\text { Chlorophyll b } \\
\left(\mathrm{mg} \mathrm{g}^{-1}\right)\end{array}$ & $\begin{array}{l}\text { Soluble sugar } \\
\left(\mathrm{mg} \mathrm{g}^{-1}\right)\end{array}$ & $\begin{array}{l}\text { Soluble protein } \\
\left(\mathrm{mg} \mathrm{g}^{-1}\right)\end{array}$ & $\begin{array}{l}\text { Root vigor } \\
\left(\mathrm{mg} \mathrm{g}^{-1} \mathrm{~h}^{-1}\right)\end{array}$ \\
\hline CPRR & $10.39 \pm 0.73^{*}$ & $1.03 \pm 0.07^{*}$ & $10.05 \pm 0.07^{*}$ & $2.72 \pm 0.09^{*}$ & $1.75 \pm 0.02^{*}$ \\
CK & $7.95 \pm 0.62$ & $0.79 \pm 0.06$ & $7.20 \pm 0.21$ & $2.10 \pm 0.10$ & $1.18 \pm 0.03$ \\
\hline
\end{tabular}

Note: Values with ${ }^{*}$ within a column are significantly different by the t-test $(p=0.05)$

\subsection{Fruit growth and yield}

The data for the size of the pineapple fruits are presented in Figures 1 and 2. The transverse and longitudinal diameters of fruits from the CPRR treatment were increased by $41.1 \%$ and $38.8 \%$, respectively, when compared with $\mathrm{CK}$. The CPRR weight per fruit was increased by $51.3 \%$, and the

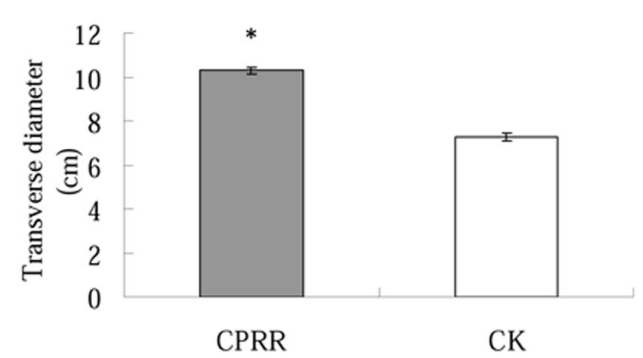

yield per plot was increased by $47.9 \%$. Statistical analyses showed that the transverse and longitudinal diameters and fruit weight and yield per plot were significantly increased after CPRR treatment. These findings are in agreement with prior reports (Abdelhamid et al., 2004; Courtney and Mullen, 2008; Siddiqui et al., 2008).

Figure 1. Size of pineapple fruits as affected by CPRR treatment 

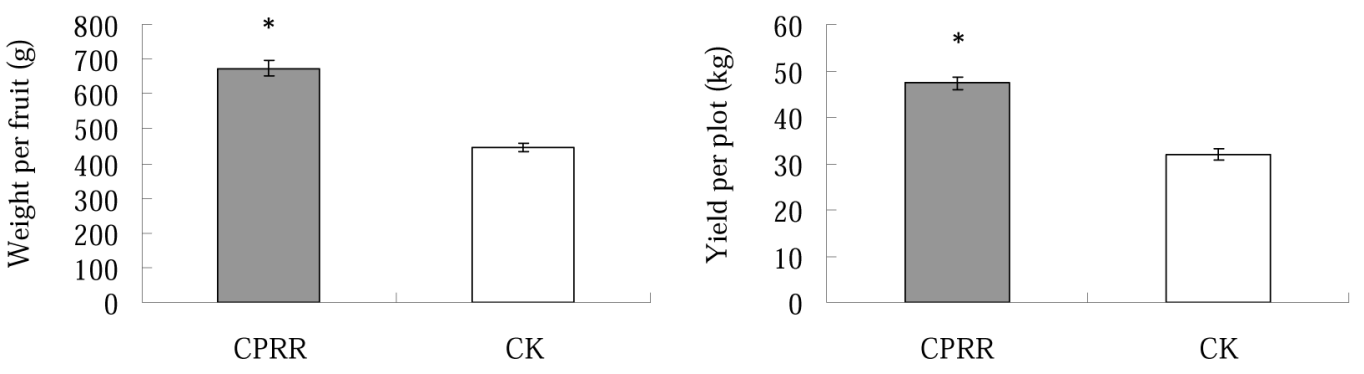

Figure 2. Weight per fruit and yield per plot as affected by CPRR treatment

Obviously, CPRR promoted the growth of nextcropped pineapple plants, as well as increased the size and yields of next-cropped fruits. However, this promotion was due to the enhancement of fertility of soil where the pineapple plants grown as affected by CPRR. As presented in this work, CPRR provided better soil environmental conditions for the nextcropped pineapple plants by decreasing the bulk density, increasing the fertility, the abundance of micro-organisms and activity of enzymes of the soil where the next-cropped pineapple grown. Just due to the better conditions, CPRR provided more positive nutritional factors for the next-cropped pineapple plants and stimulated the growth of next-cropped pineapple plants as well as increased the physiological characteristics of leaves and roots. So the growth of next-cropped CPRR fruits was promoted and yields were increased.

\section{Conclusions}

Composted pineapple residue return (CPRR) decreased the bulk density of the soil and increased the organic matter, available $\mathrm{N}$, available $\mathrm{P}$, and available $\mathrm{K}$ contents. CPRR increased the abundance of bacteria, fungi, and actinomycetes and the activities of urease, catalase, acid phosphatase, and invertase in the soil. CPRR stimulated the growth of the nextcropped pineapple plants. The chlorophyll, soluble sugar, and soluble protein contents of the leaves and root vigor were all enhanced by this practice. CPRR also promoted the growth and heightened the yield of pineapple fruits.

\section{Acknowledgements}

This work was financially supported by Sci-tech Grant (2010B031800012) from Guangdong Province of P. R. China, and Special Fund for Agro-scientific Research in the Public Interest (201203021) from Ministry of Agriculture of P. R. China.

\section{References}

Abdelhamid, M.T., Horiuchi, T., Oba, S. 2004. Composting of rice straw with oilseed rape cake and poultry manure and its effects on faba bean (Vicia faba L.) growth and soil properties. Bioresource Technology. 93, 183-189. 
Ahmed, O.H., Husni, M.H.A. 2010. Exploring the nature of the relationships among total, extractable and solution phosphorus in cultivated organic soils. International Journal of Agricultural Research. 5,746-756.

Aynehband, A., Tehrani, M., Nabati, D.A. 2010. Effects of residue management and $\mathrm{N}$-splitting methods on yield and biological and chemical characters of canola ecosystem. Journal of Food, Agriculture and Environment. 8 (2), 317-324.

Benito, M., Masaguer, A., Moliner, A., Antonio, R.D. 2006. Chemical and physical properties of pruning waste compost and their seasonal variability. Bioresource Technology. 97, 2071-2076.

Bernard, E., Larkin, R.P., Tavantzis, S., Erich, M.S., Alyokhin, A., Sewell, G., Lannan, A., Gross, S.D. 2012. Compost, rapeseed rotation, and biocontrol agents significantly impact soil microbial communities in organic and conventional potato production systems. Applied Soil Ecology. 52, $29-41$

Bougnom, B. P., Knapp, B. A., Elhottová, D., Koubová, A., Etoa, F.X., Insam, H. 2010. Designer compost with biomass ashes for ameliorating acid tropical soils, Effects on the soil microbiota. Applied Soil Ecology. 45, 319-324.

Caballero, R., Pajuelo, P., Ordovás, J., Carmona, E., Delgado, A. 2009. Evaluation and correction of nutrient availability to Gerbera jamesonii $\mathrm{H}$. Bolus in various compost-based growing media. Scientia Horticulturae. 122, 244-250.

Chikae, M., Ikeda, R., Kerman, K., Morita, Y., Tamiya, E. 2006. Estimation of maturity of compost from food wastes and agro-residues by multiple regression analysis. Bioresource Technology. 97, 1979-1985.

Courtney, R.G., Mullen, G.J. 2008. Soil quality and barley growth as influenced by the land application of two compost types. Bioresource Technology. 99, 2913-2918.

Edwards, L., Burney, J.R., Richter, G., MacRae, A.H. 2000. Evaluation of compost and straw mulching on soil-loss characteristics in erosion plots of potatoes in Prince Edward Island, Canada. Agriculture, Ecosystems and Environment. 81, 217-222.

Evanylo, G., Sherony, C., Spargo, J., Starner, D., Brosius, M., Haering, K. 2008. Soil and water environmental effects of fertilizer-, manure-, and compost-based fertility practices in an organic vegetable cropping system. Agriculture, Ecosystems and Environment. 127, 50-58.

Gabhane, J., William, S.P.M.P., Bidyadhar, R., Bhilawe, P., Anand, D., Vaidya, A.N., Wate, S.R. 2012. Additives aided composting of green waste: Effects on organic matter degradation, compost maturity, and quality of the finished compost. Bioresource Technology. 114, 382-388.

Gaind, S., Gaur, A.C. 2003. Quality assessment of compost prepared from fly ash and crop residue. Bioresource Technology. 87, 125-127.

Gandolfi, I., Sicolo, M., Franzetti, A., Fontanarosa, E., Santagostino, A., Bestetti, G. 2010. Influence of compost amendment on microbial community and ecotoxicity of hydrocarbon-contaminated soils. Bioresource Technology. 101, 568-575.

Heard, J., Cavers, C., Adrian, G. 2006. Up in Smoke - Nutrient Loss with Straw Burning. Better Crops. 90(3), 10-11.

Huang, J. C., Peng, Z. P.,Yu, J. H., Yang, L. X., Lin, Z. J. 2009. The impact of applying corn-straw compost on quality of mustard and soil fertility. Guangdong agricultural Sciences. 12, 88-91.

Joshi, D., Hooda, K.S., Bhatt, J.C., Mina, B.L., Gupta, H.S. 2009. Suppressive effects of composts on 
soil-borne and foliar diseases of French bean in the field in the western Indian Himalayas. Crop Protection. 28, 608-615.

Kowaljow, E., Mazzarino, M.J. 2007. Soil restoration in semiarid Patagonia: Chemical and biological response to different compost quality. Soil Biology and Biochemistry. 39, 1580-1588.

Li, D.X., Guo, Y. X., Yuan, H.Y., Zhang, M., Gong, X.Y., Mu, F. 2005. Determined methods of chlorophyll from maize. Chinese Agricultural Science Bulletin. 21(6), 153-155.

Li, H.S. 2000. Experimental principles and technologies of plant physiology and biochemistry. Beijing: Higher education press.

Lou, Y.L., Xu, M.G., Wang, W., Sun, X.L., Zhao, K. 2011. Return rate of straw residue affects soil organic $\mathrm{C}$ sequestration by chemical fertilization. Soil and Tillage Research. 113, 70-73.

Makoi, J.H.J.R., Ndakidemi, P.A. 2008. Selected soil enzymes: Examples of their potential roles in the ecosystem. African Journal of Biotechnology. 7 (3), 181-191.

Ribeiro, H.M., Romero, A. M., Pereira, H., Borges, P., Cabral, F., Vasconcelos, E. 2007. Evaluation of a compost obtained from forestry wastes and solid phase of pig slurry as a substrate for seedlings production. Bioresource Technology. 98, 32943297.

Roca-Pérez, L., Martínez, C., Marcilla, P., Boluda, R. 2009. Composting rice straw with sewage sludge and compost effects on the soil-plant system. Chemosphere. 75, 781-787.

Ros, M., Pascual, J.A., Garcia, C., Hernandez, M.T., Insam, H. 2006. Hydrolase activities, microbial biomass and bacterial community in a soil after long-term amendment with different composts. Soil Biology and Biochemistry. 38, 3443-3452.
Saha, S., Mina, B.L., Gopinath, K.A., Kundu, S., Gupta, H.S. 2008. Relative changes in phosphatase activities as influenced by source and application rate of organic composts in field crops. Bioresource Technology. 99, 17501757.

Shi, C.Q. 1995. Effect of heavy metal pollution on enzyme activity of soil. Chinese Journal of Soil Science. 26 (1), 34-35.

Siddiqui, Y., Meon, S., Ismail, R., Rahmani, M., Ali, A. 2008. Bio-efficiency of compost extracts on the wet rot incidence, morphological and physiological growth of okra (Abelmoschus esculentus [(L.) Moench]). Scientia Horticulturae. 117, 9-14.

Soil microbial research lab, institute of soil science, Chinese academy of sciences. 1985. Method of soil microbial research. Beijing: Science press.

Sommer, R., Ryan, J., Masri, S., Singh, M., Diekmann, J. 2011. Effect of shallow tillage, moldboard plowing, straw management and compost addition on soil organic matter and nitrogen in a dryland barley/wheat-vetch rotation. Soil and Tillage Research. (115-116), 39-46.

Tam, R.K., Magistad, O.C. 1935. Chemical changes during decomposition of pineapple trash under field conditions. Journal of the American Society of Agronomy. 27, 813-825.

Tejada, M., Gonzalez, J.L. 2006. Crushed cotton gin compost on soil biological properties and rice yield. European Journal of Agronomy. 25, 22-29.

Traversa, A., Loffredo, E., Gattullo, C.E., Senesi, N. 2010. Water-extractable organic matter of different composts: A comparative study of properties and allelochemical effects on horticultural plants. Geoderma. 156, 287-292. 
Yogev, A., Raviv, M., Kritzman, G., Hadar, Y., Cohen, R., Kirshner, B., Katan, J. 2009. Suppression of bacterial canker of tomato by composts. Crop Protection. 28, 97-103.

Zayed, G., Abdel-Motaal, H. 2005. Bio-active composts from rice straw enriched with rock phosphate and their effect on the phosphorous nutrition and microbial community in rhizosphere of cowpea. Bioresource Technology. 96, 929-935.
Zhang, J.E. 2007. Research methods and technologies for common experiments of ecology. Beijing: Chemical industry press.

Zhang, W., Gong, J.P., Liu, J.G. 2011. Effect of returning cotton stalk to long-term continuous cropping filed on soil enzyme activities. Ecology and Environment Science. 20, 881-885.

Zhao, L.P., Jiang, Y. 1986. Discussion of method of soil acid phosphatase determination. Chinese Journal of Soil Science. 3 (1), 138-141. 